\title{
Fungsi dan Peran Api dalam Seni dan Kehidupan Masyarakat Bali
}

\author{
I Gusti Ngurah Sudibya, Pande Made Sukerta, Sardono W. Kusumo, Eko Supriyanto \\ Program Studi Tari, Fakultas Seni Pertunjukan,, \\ Institut Seni Indonesia (ISI) Denpasar, Bali \\ Jalan Nusa Indah Denpasar, 80235 Bali \\ Email: igustingurahsudibya@yahoo.com
}

\begin{abstract}
Fire is made up of three elements, such as heat, combustible materials and oxygen. Fire has heat and light. Fire is used in various activities in human life from cooking, lighting marriage and burning dead bodies. Fire is available in space, on earth, and in oneself. Symbolically the fire is employed as a symbol of spirit, a sanctification, a destruction, enlightenment, heating temperatures, fire of romance, and fire of revenge. Overheated is possible when someone ignores norms, ethics, and rules.

Library studies, interviews, observations, and experiments are methods used in this article. Fire, both as symbol and text, functioned according to the capacity or its role, both in and outside themselves. The use of it must be controlled for the harmony of the macrocosms and microcosms, when is the right time is to use small, medium, and large fire, because all of them is important.
\end{abstract}

Keywords: function, fire, symbol, harmony

\begin{abstract}
ABSTRAK
Api terbentuk dari tiga elemen, yakni panas, bahan mudah terbakar dan oksigen. Api memiliki panas dan cahaya. Api digunakan dalam kehidupan manusia dari memasak, penerangan, perkawinan sampai pembakaran jenazah. Api terletak di angkasa, di bumi, dan dalam diri. Api dijadikan simbol semangat, penyucian, peleburan, pencerahan, api asmara, api dendam. Panas (over heated) berlebih terjadi ketika seseorang tidak lagi mengindahkan norma, etika, aturan.

Studi kepustakaan, wawancara, observasi, dan eksperimen merupakan metode yang digunakan dalam tulisan ini. Api, baik sebagai simbol maupun teks, difungsikan sesuai kapasitas/perannya masing-masing, baik dalam diri maupun di luar diri. Penggunaannya hatus dikendalikan agar keharmonisan bhuana alit dan bhuana agung dapat terwujud, kapan menggunakan api kecil, sedang maupun besar, karena semuanya penting.
\end{abstract}

Kata kunci: fungsi, api, simbol, harmoni 


\section{PENDAHULUAN}

Api atau agni adalah salah satu unsur terpenting dari tradisi budaya Bali. Masyarakat Hindu di Bali, yang memandang api sebagai benda biasa (sekala) dan agni sebagai perwujudan kekuatan suci (niskala), menggunakan api dalam berbagai aspek kehidupan spiritual, sosial, dan kultural. Semuanya ini menunjukkan betapa vitalnya budaya api dalam tradisi Bali.

Pengalaman dan penjelajahan terhadap budaya api di kalangan masyarakat Bali menunjukkan betapa sentralnya api dalam kehidupan masyarakat Pulau Dewata. Dalam kehidupan spiritual, api digunakan pada pelaksanaan dari kelima bagian upacara Panca Yadnya masyarakat Hindu di Bali, yakni Dewa yadnya, Pitra yadnya, Manusa yadnya, Rsi yadnya, dan Bhuta yadnya. Hampir tidak ada upacara yadnya yang dilaksanakan umat Hindu di Bali tanpa melibatkan api, di antaranya dalam bentuk dupa, pasepan, dan api linting. Dalam kehidupan sosial sehari-hari, api juga menjadi kebutuhan masyarakat. Selain untuk memasak dan menghangatkan badan (di kala musim dingin), api juga masih sering digunakan untuk membersihkan lahan-lahan pertanian di sawah. Untuk melindungi warga masyarakat, awig-awig atau peraturan tertulis setiap desa di Bali juga mencantumkan pasal-pasal (pawos) yang berkaitan dengan bencana api. Dalam kehidupan kultural, khususnya di bidang seni, api juga digunakan dalam sejumlah seni pertunjukan, seperti wayang kulit, tari Sanghyang, dan tari Cak.

Api tidak dapat lepas dari penemuan perjalanan prosesi kehidupan spritual dan religius di Bali. Api menjadi begitu penting untuk menunjang pelaksanaan upacara keagamaan, khususnya umat Hindu, sebagai wujud prilaku menghormati kebesaran Tuhan, termasuk nilai-nilai api yang tekandung di dalamnya.

Perjalanan hidup manusia di alam semesta berlangsung dalam proses pencarianmakna- makna kehidupan yang terbingkai dalam tatanan nilai budaya. Hal itu melibatkan kompleksitas kehidupan membudaya yang menerpa ke berbagai aspek sosiokultural dengan polapola perilaku mulai dari aktivitas berpikir, berucap sampai pada tindakan nyata (Chaya, 2014: 296).

Sebelum pelaksanaan upacara keagamaan dimulai, didahului dengan menyalakan api baik api dupa, lampu minyak kelapa, maupun pasepan. Menurut beberapa sumber, penggunaan api yang menonjol itu, disebabkan sifat api yang memiliki panas dan cahaya. Panasnya meresap ke seluruh pelosok, baik ke dalam tanah, ke angkasa, kayu, daun, tumbuhan, mahluk hidup maupun tubuh manusia. Sementara cahayanya menyebar keseluruh penjuru, kecuali terhalang. Gerak apinya yang berkobar melambangkan semangat. Asapnya yang putih dengan harum mewangi membumbung ke udara kemudian menyatu di udara. Sifat yang demikian itu menyebabkan api diyakini sebagai pembawa persembahan manusia kepada Ida Hyang Widi Wasa, Tuhan Yang Maha Kuasa sebagai pencipta alam beserta isinya.

Api selalu menimbulkan nyala baru dan dianggap sebagai penunjuk jalan, pembimbing dan penolong bagi mereka yang sedang dalam kesusahan atau kegelapan. Api yang nyalanya berkobar-kobar akan membakar apa saja yang dilemparkan kepadanya, sehingga api dianggap sebagai pembasmi malapetaka (Titib, 2003: 140).

Api digunakan oleh manusia sejak lahir, hidup sampai mati. Hal ini dibuktikan dengan api yang terdapat dalam dirinya dan berbagai api yang ada di luar dirinya. Menurut Ida Pedanda Gede Djelantik Putra Tembuku, ada tiga tempat api, pertama, api di angkasa, yakni api yang ada di langit seperti matahari dan petir. Kedua, api di dalam ibu pertiwi, contohnya dapat dilihat di dalam gunung berapi yang aktif. Letupan lava membuktikan ada api dalam bumi. Yang ketiga adalah api di dalam diri. Api dalam diri ini terdapat di dalam jan- 
tung, sehingga menyebabkan darah yang beredar dan tubuh manusia menjadi "panas". Tanpa adanya api dalam diri manusia, manusia akan mati (wawancara, 20 Oktober 2014).

Menurut Ida Pedanda Gede Putra Bajing, api dapat dilihat dari dua bentuk, yakni api yang menyala (api), dan api yang tidak menyala (bara: nyarirem ditempatkan dalam diri). Manfaat api adalah sebagai utpeti (pencipta), setiti (memelihara atau disebut juga angkara tarpanalpedamaran) serta pralina (melebur atau api pengesengan: ngaben/pengembalian kepada Panca Maha Bhuta). Unsur pangiwa/black magic/pangeleakan juga menggunakan unsur api. Selain itu, di dalam tubuh (bhuana alit) dan di luar tubuh (bhuana agung) sama-sama terdapat unsur: api-air-angin. Alam telah mengajarkan tentang "keseimbangan" (wawancara, 23 Oktober 2014).

Sebuah tabloid yang mengungkap kemampuan mengolah api dalam diri untuk menangkal wisia leak atau kejahatan dari ilmu hitam (apinya berwarna merah).

Di ujung api dalam konteks kebatinan disebut memiliki taring api. Oleh para praktisi kebatinan, taring api inilah dibelokan sehingga tubuh dapat bertahan lebih lama menahan panas, karena taring panasnya ini lambat masuk dalam tubuh. Memperlambat ini ada beberapa ajian yang bisa dipergunakan untuk ngepus caling api (taring api) adalah istilah titik panas api yang terletak diujung api itu sendiri yang dapat dibelokan dengan menggunakan ilmu kebatinan sehingga panasnya lambat, di antaranya Brahma Murub, Segara Geni, Wisnu Kunda Wijaya, Sanghyang Geni Kalis, Suwuk Geni, Tameng Geni, Pangenduh Geni, Aji Penautan, Geni Astra Pangesengan, Pengamaramar. Ajian tersebut dapat digunakan untuk menundukkan caling api sehingga titik panasnya bisa dibelokan agar tidak cepat membakar (Tabloid Bali Niskala, edisi 38, $2017: 20)$.

Over heated atau panas berlebih terjadi hampir di segala lini kehidupan. Dunia politik, anak-anak muda yang tidak lagi menghormati bahkan ada yang membunuh orang tuanya, aturan dilanggar, pergaulan seks bebas yang ditimbulkan akibat api asmara yang tidak terkendali, dan masih banyak kejadian lainnya yang diakibatkan oleh tidak terkontrolnya api yang ada dalam dirinya. Instropeksi diri, pengendalian diri atau mulat sarira tidak lagi maksimal dalm dirinya sehingga panas berlebih ini menjadi semakin liar. Api merupakan salah satu unsur dari Panca Maha Bhuta (Panca Maha Bhuta adalah lima elemen dasar pembentuk alam, baik alam mikrokosmos/badan manusia maupun alam makrokosmos/alam semesta); empat lainnya adalah air, angin, tanah, dan gas. Lima unsur alam ini selain terdapat di alam raya, bhuana agung, juga terdapat di dalam diri manusia, bhuana alit. "Padat adalah unsur pertiwi, cair adalah unsur apah, panas dan sinar mata adalah unsur teja, paru-paru adalah unsur bayu, sembilan lubang adalah unsur akasa" (Mangku Alit Pekandelan, 2010: 21).

Dalam buku Sarasamuscaya yang berisi tentang ajaran agama Hindu, salah satunya menjelaskan tentang api dalam kehidupan manusia yang harus dijaga, yakni "tryagni; ahawaniya, yakni api untuk memasak makanan; garhaspatya, yakni api dalam perkawinan; dan citagni yakni api membakar jasad (ngaben) sebagai bentuk pengembalian Panca Maha Bhuta kepada alam semesta" (Kadjeng, 1997 : 53). Jadi, api begitu penting disemua lini kehidupan. Api yang ada dalam diri manusia, mulai sejak lahir, dibesarkan dan sampai kembali keasalnya merupakan siklus yang tidak dapat dibantah.

Pengamatan atas proses pembuatan gamelan (gong) di perapen Bapak Supoyo di Desa Wirun, Sukoharjo, Solo, dalam ruang yang cukup luas, dengan menggunakan dua tungku pembakaran membuat suhu udara di ruangan itu cukup panas. Semburan bara api akibat membolak-balik gong yang sedang dilebur membuat desaign menarik yang bergerak ke udara dengan warna oranye dan cream. Sementara bara 
kayu jati yang tetap membara di tempat itu mengeluarkan warna kebiruan, kemerahan, kekuningan bercampur menjadi satu kesatuan lingkaran yang disembur dengan angin dari blower. Hal ini sangat menarik dalam gradasi terang redup bara api.

Seni pertunjukan wayang yang menggunakan penerangan berupa api/lampu blencong membuat bayangan wayang di kelir terus bergerak, dan menjadi hidup. Penggunaan dupa dalam rutinitas ritual keagamaan di lingkungan sendiri sebagai saksi sekaligus simbol bahwa upacara disaksikan oleh Dewa Surya, dan doa yang dipanjatkan agar menyatu dengan Tuhan, seperti asap yang dikeluarkan oleh dupa itu sendiri. Prosesi keyakinan terhadap api sebagai simbol keberanian dan semangat juga dapat disaksikan pada saat sambuk, perang api. Sabut kelapa yang dibakar, dilemparkan oleh satu kelompok kepada kelompok lain, sebagai wujud sportivitas dan ketajaman pikiran mencari sasaran. Perang api merupakan perang dengan menggunakan prakpak yang digenggam dan dibenturkan dengan prakpak lainnya. Selain sebagai simbol keberanian dan semangat, api prakpak juga untuk membakar segala sifat buruk/kegelapan yang ada dalam diri, fisik nanon fisik. Hal ini tidak lepas dari “berbagai kemungkinan respons eksternal maupun internal yang mesti dihadapinya. Adaptasi dengan ruang, waktu, dan kondisi" (Widaryanto, 2015: 42).

Percobaan-percobaan juga dilakukan untuk mencari efek yang terjadi. Membakar spiritus di lantai, membakar sedotan/ pipet, obor diperciki spiritus, fire passing, api drum, api jambangan. Semuanya memberi efek berbeda sesuai dengan bahan dan media pembakarnya.

Dari penjelasan tersebut di atas, api yang terbentuk dari elemen panas, bahan mudah terbakar dan oksigen ini memberikan pemahaman bahwa api sangat dibutuhkan dalam kehidupan, baik untuk kehidupan itu sen- diri maupun untuk seni. Tetapi, yang lebih penting adalah pengendalian diri dalam pengunaannya. Kapan menggunakan api kecil, kapan menggunakan api sedang dan kapan menggunakan api besar. Semuanya penting tetapi untuk tetap disesuaikan dengan desa - kala - patra (tempat - waktu - keadaan).

Berbagai bentuk kesenian dapat dijadikan persembahan kepada Tuhan sebagai upaya pendekatan diri kepadaNya. "Tuhan sebagai sumber segalanya diyakini memiliki sifat-sifat Satyam (Kebenaran), Siwam (Kesucian) dan Sundaram (Keindahan)" (Dibia, 2003: 98). Kemudian, bagaimana dengan api? Apakah api memiliki nilai yang dimiliki Tuhan yakni Satyam (Kebenaran), Siwam (Kesucian) dan Sundaram (Keindahan)? Pembahasan ini bertujuan untuk memahami api dalam berbagai konteks dan mebangkitkan kesadaran dalam menggunakan "api" yang ada dalam diri untuk keharmonisan bhuana alit dan bhuana agung.

\section{METODE}

Mewujudkan sesuatu membutuhkan cara-cara tertentu yang diyakini dapat memberi kemudahan dalam berproses, begitu pula berbagai cara tersebut dapat ditempuh untuk mencapai tujuan tertentu. Aplikasinya disesuaikan dengan situasi dan kondisi yang ada agar cara yang digunakan dapat mewujudkan tujuan dengan baik. Teknik sebagai istilah yang secara spesifik merupakan cara dalam memecahkan masalah tertentu yang ditemukan dalam melaksanakan prosedur. Cara itu lazim disebut dengan metode. Adapun metode yang digunakan dalam penulisan artikel ini adalah studi kepustakaan, wawancara, observasi, dan percobaan/eksperimen.

1. Studi kepustakaan dilakukan untuk memperoleh data yang bersifat sekunder. Tujuannya untuk mengetahui informasi-informasi yang berhubungan dengan materi atau topik yang diangkat. 
2. Wawancara merupakan cara yang digunakan untuk mendapatkan keterangan lisan dari responden. Dilakukan dengan cara bercakap-cakap dan berhadapan muka.

3. Observasi merupakan pengamatan yang dilakukan dengan cara mengamati objek penelitian kemudian melakukan pencatatan agar memperoleh data yang diperlukan.

4. Percobaan, yakni mengejakan sesuatu untuk mengetahui hasilnya. Pencatatan dilakukan dengan dokumentasi maupun tulisan.

\section{HASIL DAN PEMBAHASAN}

Tuhan memiliki sifat Kesucian, Kebenaran, dan Keindahan yang diyakini oleh umat Hindu, khususnya di Bali. Tuhan adalah sumber dari segala sumber. Salah satu ciptaan Tuhan yang membantu kelangsungan hidup manusia adalah api. Api memiliki dua bentuk. Pertama, api disebut dengan istilah api sekala, yang secara kasat mata dapat dilihat sebagai api keseharian seperti api yang dipakai memasak, membakar sesuatu, api unggun, api lampu blencong, api lilin, api dupa, dan bentuk api lainnya. Sementara itu, api dalam bentuk yang kedua disebut dengan api tidak nyata atau disebut dengan istilah api niskala. Api ini dapat dilihat dalam bentuk nilai-nilai yang terkandung di dalamnya. Yakni, sebagai nilai semangat untuk terus berkobar, nilai ketegasan karena sifatnya melalap habis yang berani mendekat ke dalamnya, maupun nilai kesucian yang memiliki nilai peleburan terhadap mala atau kotor/dosa/ keburukan atau segala hal yang mengandung unsur negatif baik dalam diri maupun di lingkungan.

Api bersumber dari Tuhan, karena api bersumber dari Tuhan maka api juga memiliki sifat Kesucian, Kebenaran, dan Keindahan. "Api disebut agni dalam kitab suci Hindu (Veda/Weda). Menurut Ida Pedanda Geria Telabah, bahwa kata pertama yang terdapat dalam kitab suci Reg Weda adalah agni. Yoga Puja Pedanda menggunakan agni, pada saat nyurya sewana, ritual yang dilaksanakan setiap pagi saat matahari terbit. Ngardi tirta atau membuat air suci juga menggunakan "dipa” (Geni/api), api takep dalam upacara Masegeh, dengan dua buah sarabut kelapa yang ditumpuk saling berhadapan atas dan bawah, tengadah-tengkurep, sebagai simbol pertemuan akasa-pertiwi atau langit dan bumi. Selain itu, terdapat pula gni arcanam yang dipakai sebagai sarana pengusir wabah yang divisualkan melalui tari Sanghyang Dedari, Sanghyang Jaran.

Selain itu, ada Geguritan Sebun Bangkung. Geguritan berarti gegitan atau lagu, se berarti satu, bun berarti pohon menjalar atau sebatang tali/akar panjang yang berbelit, untaian akar. Bang pada Bangkung berarti merah/api dan Kung berarti samara/kebahagiaan. Geguritan ini merupakan nyanyian Bali yang tergolong dalam sekar alit/macepat diciptakan oleh Dang Hyang Nirarta/Dwijendra menggunakan pupuh Pucung. Ia merupakan konsep serba tiga yang juga membahas tentang api, yakni Api Brahma - Api Wisnu - Api Siwa (wawancara, Selasa, 20 Juni 2017 ). Selanjutnya, beliau juga menjelaskan bahwa api juga terkait dengan Kama Sutra yang mengajarkan tentang purna (sempurna) tetapi kata purna bergeser menjadi kata "porno". Pada kitab suci Reg Weda (menyeluruh/komprehensif) pada Mandala IX, kata pertama yang disebutkan adalah api, yakni "Agnim mile purohitam yogyasia dewam rip wijam hotaram ratna dataman ...". (Wawancara, Minggu Paing, 24 September 2017 - 10:13 WITA).

Api dapat menghancurkan, membinasakan, dan dapat pula membantu maupun membahagiakan kita dalam menjalani hidup. Semua itu tergantung kemampuan kita mengolah atau mengatur maupun menggunakannya karena apapun yang dilakukan tidak dapat lepas dari hukum sebab akibat. Seperti halnya agni sebagai penganugerah 
kemakmuran dan kebahagiaan. Ia disebut saksi yang tetap eksis sampai kini dalam setiap pemujaan umat Hindu" (Titib, 2001: 168).

\section{Api dalam Kesucian}

"Aktivitas apapun ketika menyangkut nilai-nilai ketuhanan, merupakan sebuah persembahan atau yadnya. Lebih-lebih dalam dunia seni di Bali, selalu mengacu kepada estetika yang diikat oleh nilai-nilai spiritual sesuai dengan ajaran agama Hindu" (Dibia, 2003: 97). Kesucian juga bermakna bebas dari kotor dan noda. Hal ini menjadi penting ketika kita sadar untuk menjaga alam beserta isinya agar tidak kotor dan ternoda. Pengalaman penulis ketika menerima sebuah acara sesi pemotretan tari Jaran Gading/Sanghyang Jaran bahwa atas asumsi hanya pemotretan, penyucian terhadap sarana pertunjukan tidak dilakukan. Apalagi pementasan ini tidak dilaksanakan dalam rangka mengusir wabah. Akibatnya, setelah menari (sebelum pulang) kaki penari Jaran mengalami luka bakar serius dan gelisah sepanjang malam. Keesokan harinya, sesuai dengan keyakinannya terpaksa dilakukan ritual ulang dengan sesaji relatif besar serta mohon maaf atas keteledoran yang terjadi. Dalam bahasa Bali disebut ampah (menganggap sepele). Kejadian ini memberi pelajaran yang tidak pernah terlupakan sampai detik ini. Pengalaman ini juga lebih meyakinkan lagi tentang nilai-nilai kesucian harus tetap dilestarikan seringan apapun pekerjaan yang dilakukan. Nilai kesucian menjadi penting seperti "ruwatan yang mementaskan wayang sebagai upaya pembebasan dari kekhawatiran terhadap krisis yang mungkin terjadi" (Tri Mulasno, 2007: 167).

Aktivitas religius umat Hindu selalu menggunakan unsur api dalam bentuk pasepan, dupa, maupun nyala api minyak kelapa. Pedanda/Pandita yang mengantarkan puja juga menggunakan pedamaran/api suci. Api yang digunakan ini melalui proses penyucian mulai dari persiapan bahan bakar minyak kelapa, sumbu, tempatnya, dan waktu menyalakannya. Penyucian terhadap dupa yang dipakai sembahyang juga dilakukan ritual penyucian dengan mantra: “Om Am dupa dipastraya nama swaha." Artinya, "Ya Tuhan, tajamkanlah nyala dupa hamba sehingga sucilah sudah hamba seperti SinarMu" (Pustaka Manik Geni, 1994: 9).

Setiap manusia di dunia ini dapat melihat api dari berbagai perspektif sesuai kemampuan dan kebutuhannya, begitu pula dalam konteks lainnya. Api dapat dilihat dari dua bentuk, berupa teks/tanda dan simbol. Sebagai tanda, ia adalah bagian dari "dunia fisik" yang berfungsi sebagai operator dan memiliki substansi, sedangkan simbol merupakan bagian dari "dunia makna" manusia yang berfungsi sebagai designator (Yuda, 2000: 8). Dari penjelasan itu, kiranya dapat dicarikan contoh ketika kita menyalakan obor, api dalam obor itu dapat dilihat sebagi sebuah sesuatu yang mengeluarkan cahaya untuk menerangi sekitar. Tetapi, dalam waktu bersamaan api obor itu dapat pula dilihat sebagai sebuah simbol, seperti api PON atau api olimpiade. Yakni, sebagai simbol semangat yang dilihat dari gerak apinya sendiri sebagai kekuatan yang penuh energi untuk menjadi yang terbaik. Sepanjang bahan bakar masih tersedia, api tidak akan pernah mati. Mungkin ini yang dijadikan dasar oleh pendahulu sehingga api digunakan sebagai simbol agar semangat tetap berkobar.

Hal ini tergantung sepenuhnya kepada kita apakah melihatnya sebagai sebuah teks saja, atau sebagai simbol saja. Sebab, tidak dipungkiri satu benda atau satu objek seperti api ini dapat menjadi teks sekaligus simbol. Hal itu tergantung pada kemampuan yang kita miliki dalam melihat sebuah objek.

Api dijadikan simbol peleburan untuk mengembalikan unsur Panca Maha Bhuta kepada asalnya melalui upacara Ngaben. Api dan kayu bakar yang digunakan untuk 
pembakaran jenazah ini disucikan terlebih dahulu diletakkan di tempat suci di pura Prajapati oleh Brahmana atau pelaku spiritual. Pengertiannya, anak membantu orang tua yang wafat untuk mengembalikan utangnya/swadarma. Seorang anak melaksanakan Pitra Yadanya untuk orang tuanya atau leluhurnya.

"... Setiap ego berutang Kama Bang dan Kama Petak (darah merah dan darah putih) pada orang tuanya. Orang tua berutang unsur stula sarira pada Panca Maha Bhuta. Bila orang tuanya meninggal, keturunannyalah yang wajib membantu "membakar" (membayari utang) stula sarira orang tuanya hingga kembali manunggal dengan Panca Maha Bhuta" (Kaler, 1993: 8).

Di atas jenazah yang telah diupacarai, diletakkan sebuah pelita kecil terbuat dari kulit telor ayam berbahan minyak kelapa. Ditopang dengan setangkai kayu kecil yang artistik, ditanam pada "pot buah kelapa" yang dikupas halus. Lampu ini dinyalakan sebagai simbol hati atau manah mendiang, berfungsi mengantarkan spirit ke bhuana agung. Bersamaan dengan dinyalakannya pelita yang disebut angenan ini, di luar pekarangan rumah juga dinyalakan lampu minyak kelapa yang disebut Damar kurung. Api ini menjadi simbol untuk membatasi noda dan pancaran cuntaka oleh pelaksanaan pangabenan ini agar tidak meluas ke wilayah lain (Kaler, 1993 : 16, 63).

Pelaksanaan ngaben ini tergantung pada kemampuan yang melaksanakan upacara karena di dalamnya terkandung nilai ketulusikhlasan, seni, sopan santun, etika, kehalusan budi, keharuan serta simbolik lainnya. Adaptasi pun dilakukan terhadap desa kala patra manakala finansial yang menjadi penunjang. Seperti Pelebon di Puri Ubud yang memakan dana milyaran rupiah maupun warga desa yang hanya bermodalkan beberapa juta rupiah saja tetap dapat melaksanakan upacara ngaben.

Caru sebagai wujud nyata pelaksanaan ritual penyucian dilaksanakan untuk dua

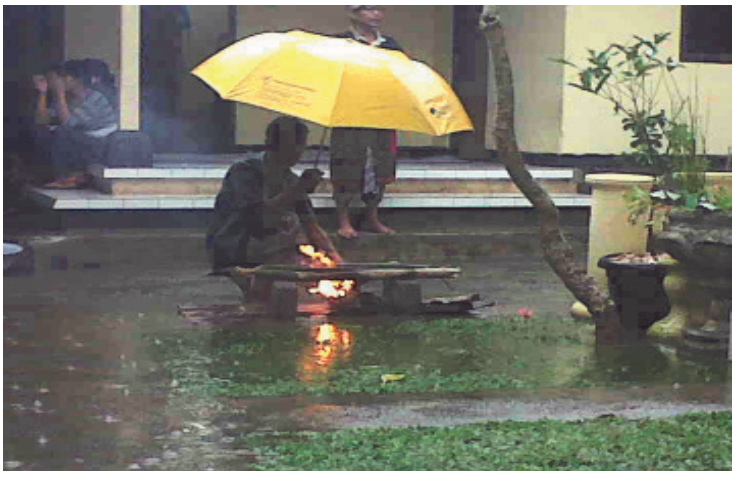

Gambar 1. Membakar tetimpug untuk mengusir aura negatif yang di pekarangan rumah

Foto: I Gusti Ngurah Sudibya, 2014.

hal. Pertama penyucian tempat, kedua penyucian sasih/waktu. Penyucian tempat, umumnya dilakukan untuk menyucikan lahan baru untuk pekarangan rumah, balai banjar, balai desa, kantor. Sedangkan untuk penyucian waktu contohnya adalah caru/ tawur agung kesanga yang dilaksanakan sehari sebelum hari raya Nyepi. Upacara caru ini bertujuan agar keseimbangan dan keharmonisan alam beserta isinya tetap terjaga dari pengaruh negatif (Wikarman, 2006: 14). Salah satu unsur penyucian itu selain menggunakan sesaji, mantra, pelengkap lainnya, sarana dupa, juga menggunakan api untuk membakar tetimpug.

Tetimpug merupakan ruas bambu kedua ujungnya masih tertutup secara alami yang diikat menjadi satu kemudian dibakar. Bunyi yang ditimbulkan akibat ledakan ini sebagai tanda memanggil kekuatan negatif untuk diberi sesaji agar tidak lagi mengganggu manusia.

Dalam pertunjukan tari Sang Hyang Jaran, sebelum pementasannya dilakukan ritual penyucian kepada penarinya, alat yang digunakannya, sekaligus memohon keselamatan dan kesuksesan penampilan. Yang sempat penulis saksikan ketika masih duduk di bangku Sekolah Dasar, di sebuah pelataran di area paling luar (jaba) sisi Pura Puseh Desa Bona, penari Sang Hyang Jaran jongkok sambil memegang jarannya diasapi dengan asap pasepan yang beraro- 
ma harum oleh seorang pemangku dengan mengibaskan sebuah penutup sesaji kecil ke arah penari. Lantunan nyayian koor lakilaki terus dilantunkan sampai penari Sang Hyang Jaran rebah dan berputar di tempat, dan selanjutnya memburu api sabut kelapa yang sudah membumbung tinggi di tengahtengah arena pertunjukan. Api ini kemudian dimainkan hingga habis.

Penari Arja yang disaksikan di Desa Singapadu-Gianyar, penari Baris Gede dan Rejang di pura Besakih, Karangasem juga menancapkan dupa di hiasan kepalanya. Selain untuk kesucian, juga untuk keselamatan. Apa yang dipersembahkan agar mendapat rido karena disaksikan langsung oleh Dewa Agni. Hal ini merupakan bentuk warisan bahwa "secara keseluruhan kelompok manusia pada jaman dulu memiliki suatu pemahaman bahwa segala kejadian fisik selalu berkaitan dengan dewa-dewa" (Maharani, 2016: 395).

Pemahaman lainnya terkait api adalah adanya lima aspek wujud api ritual atau kesucian, yakni:

a. Brahma Agni (api yang sangat luas) digunakan selama pelaksanaan upacara yang muncul sebagai api dunia.

b. Prajapatya Agni, api yang diberikan kepada para Brahmacari, mempersembahkan upacara Agnihotra.

c. Garhyapatya Agni, api untuk kepentingan keluarga yang diperoleh setelah upacara perkawinan. Api ini hendaknya dipelihara selama hidup.

d. Daksina Agni, api yang digunakan dalam persembahan kepada leluhur.

e. Kravyada Agni, api yang digunakan dalam upacara pembakaran jenazah (Danielou dalam Titib, 2003: 170).

Ritus kematian dalam kehidupan zoroatrianisme tidak mengijinkan penguburan dan pembakaran jazad manusia karena dianggap akan menodai air, udara, bumi, dan api. Mereka begitu mengagungkan dewa Agni sampai melarang melakukan pemba- karan terhadap jasad manusia. Dalam hal ini mayat tidak boleh disentuh oleh "api" sehingga mayat ini digeletakkan begitu saja di sebuah kuil. Daging yang membusuk itu akan habis dimakan burung pemakan bangkai dan binatang lainnya (https:// id.m.wikipedia.org, 25/3/2018).

Sementara di Bali terdapat pura yang disebut sebagai Pura Hyang Api. Dari sekian banyak pura Hyang Api di Bali, salah satunya adalah pura Hyang Api di Desa Kelusa. Pura ini adalah salah satu pura kuno di Bali yang diperkirakan telah ada sejak abad ke-8 Masehi. Yaitu, pada era Maharsi Markandeya mengembangkan konsep ajaran Agama Siwa di Bali. Berdasarkan petikan prasasti Bali kuno, bahwa pura Hyang Api adalah sthana (parhyangan) Dewa Api (dewa Agni) atau dewa Brahma dalam konsep Tatwa Nawadewata yang memiliki kesaktian memberkahi kesehatan/keselamatan umatnya. Api obor Porprov Bali XIII 2017 pun diambil dari pura Hyang Api Desa Adat Kelusa, Kecamatan Payangan, Kabupaten Gianyar, Bali. Api ini tidak diambil begitu saja tetapi diawali dengan ritual/upacara adat yang dipimpin oleh sulinggih atau pemangku. Sebagai maanusia yang menghormati dan mengangungkan milik Tuhan, tentunya permisi dan memohon kepadaNya untuk kesehatan dan keselamatan seluruh komponen terkait selain tetap memotivasi untuk semangat dalam beraktivitas. Api ini digunakan untuk menyalakan api Porprov Bali di Qualdron Stadion Dipta Gianyar, pada 17 Sepember 2017 (Koranjuri.com, 25/3/2018).

Dalam mantram pertama, sūkta pertama, mandala pertama dalam kitab suci Rgveda, Agni disebut Purohita para dewata dan penganugerah kemakmuran dan kebahagiaan. Ia disebut sebagai saksi yang tetap eksis sampai kini dalam setiap pemujaan umat Hindu.

Bade dan lembu pada gambar 2 dan gambar 3 sedang dipersiapkan untuk upa- 


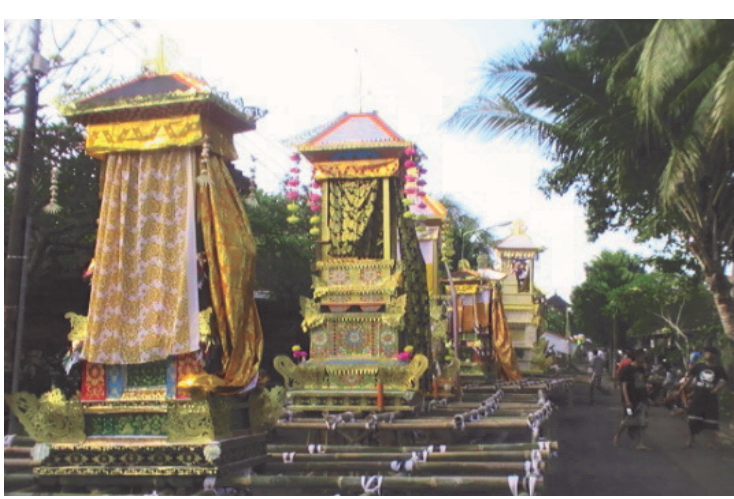

Gambar 2. Bade/Wadah (usungan jenazah) Foto: I Gusti Ngurah Sudibya, 2015

cara penyucian/melaspas terkait pelaksanaan Ngaben Masa yang dilakukan secara kolektif di Desa Bona pada tanggal 27 Juni 2015. Persiapan pelaksanaannya dilakukan secara berkelompok di balai banjar untuk memudahkan koordinasi. Adapun warga yang tidak turut serta dalam upacara dapat membantu/gotong royong karena semua kegiatan terpusat di satu tempat.

Semetara itu, pada 21 Mei 2017 salah satu keluarga di Banjar Bona Kelod Desa Bona melaksanakan upacara Ngaben/Pelebon di Kuburan/Setra Ageng di Desa Bona.

Demikian, api hendaknya tetap dijaga dan disucikan sebagai berkah dalam menjalani hidup agar selalu dalam lindungan Ida Hyang Widi Wasa/Tuhan Yang Maha Esa.

\section{Api dalam Kebenaran}

Yang dimaksud api dalam kebenaran adalah menyangkut nilai kejujuran, ketulusan, dan kesungguhan. Api tidak pernah bohong, api pasti panas, hanya kualitas panasnya yang berbeda, walaupun api dibawah 800 derajat itu ada yang mengklasifikasikan api dingin. Suhu ini karena dibandingkan dengan api yang memiliki suhu di atas 1.200 derajat atau lebih (proses pembakaran keramik). Tetapi, berdasarkan realitas yang dirasakan dan dialami, sekecil apapun api, ia tetap panas. Api memiliki panas dan cahaya sebagi hasil oksidasi cepat antara panas, bahan mudah terbakar dengan oksigen. Seberapa besar cahaya apinya sebesar itu pula kemampuannya

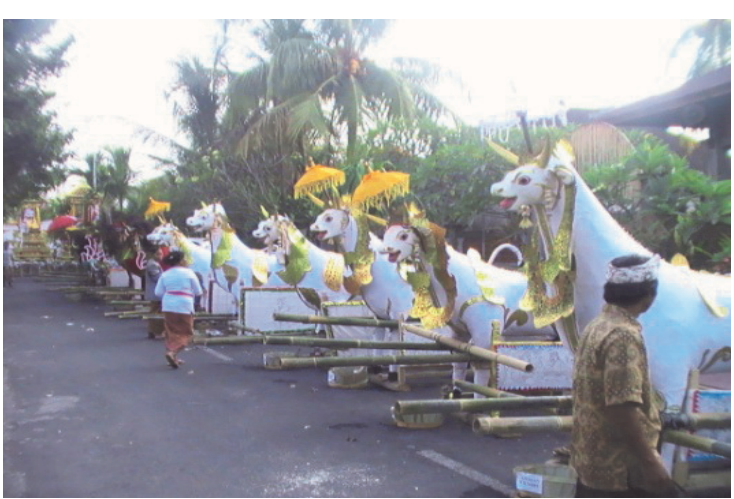

Gambar 3. Lembu tempat membakar jenazah Foto: I Gusti Ngurah Sudibya, 2015

menerangi sekitarnya. Semakin besar wujud api semakin luas pula area yang diterangi. Di sini, api sangat tulus. Seberapa banyak bahan bakarnya selama itu pula ia akan menyala. Kesungguhannya pun dapat dilihat ketika api melalap habis yang berani berada dalam wilayahnya. Api tidak pernah main-main. Hanya kitalah yang harus mampu mengolah untuk kepentingan manusia itu sendiri. Seperti pepatah, api dapat menjadi kawan maupun lawan. Dalam konteks kepemimpinan, api dapat dijadikan teladan. Yakni, mampu memberi penerangan, perlindungan serta kehidupan. Hal serupa sesuai dengan pendapat Edi Sedyawati, api memiliki makna tegas dan tuntas. Sifat-sifat baik sesuai dengan ajaran Astabrata pada poin (f) disebutkan bahwa,

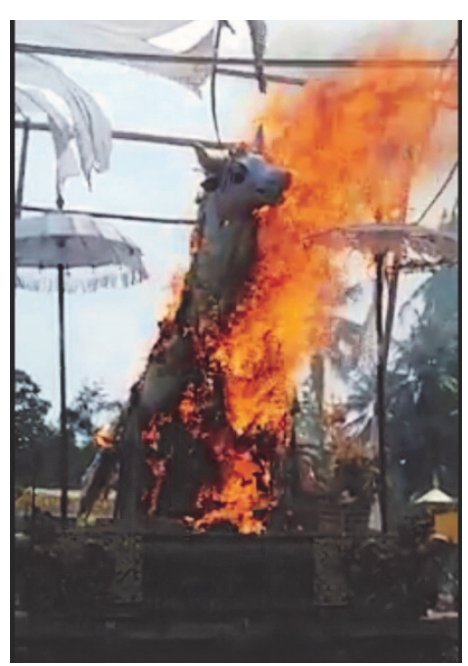

Gambar 4. Api suci membakar jenazah Foto: I Gusti Ngurah Sudibya, 2017 
Dewa Agni/Brama, bratanya ialah sifat dan watak Dahana atau api. Api memiliki kemampuan untuk membakar habis dan menghancurkan segala sesuatu yang bersentuhan dengannya. Seorang pemimpin hendaknya berwibawa dan berani menegakkan hukum dan kebenaran secara tegas dan tuntas tanpa pandang bulu (Dharsono, 2013: 25).

Aktivitas makan adalah kebutuhan setiap manusia. Makanan yang dimakan tentu ada yang harus dimasak. Memasak membutuhkan api, minimal panas. Panas adalah sifat dari api. Walaupun sekarang sudah ada rice cooker, ia membutuhkan panas dari listrik. Sementara listrik bersumber dari tenaga uap dari bumi. Dalam bumi ada api, manusia memanfaatkan uap dari panas bumi ini untuk menghasilkan listrik, dan listrik diubah arusnya menjadi energi panas untuk berbagai kebutuhan manusia, salah satunya adalah memasak. Rutinitas dalam keluarga di Bali utamanya keluarga Hindu di lingkungan sekitar, setelah memasak menghaturkan sesaji (banten saiban) sebagai ucapan terimakasih dan puji syukur kepada Sang Pencipta dalam manifestasi beliau sebagai Dewa Agni maupun Dewa Brahma (api) atas berkah yang telah dilimpahkan. Melalui sarana api, bahan mentah dapat menjadi matang.

Api hadir secara nyata di setiap kehidupan manusia. karena seperti yang telah disebutkan di atas, api ada di angkasa, di bumi dan di dalam diri. Api di angkasa diyakini berada di matahari yang selalu ada setiap saat. Hanya saja atas perputaran bumi kita memeroleh gelap dan terang secara bergantian, meski sesungguhnya matahari ada dalam 24 jam. Begitu juga api yang ada di dalam bumi, ia selalu ada dan dapat dilihat di dalam kawah gunung berapi, atau api abadi yang muncul dari celah bumi di beberapa daerah di pulau Jawa. Bahkan, ada yang digunakan untuk memasak dan membakar jagung oleh warga sekitarnya. Menurut Ida Pedanda Gede Djelantik Putra

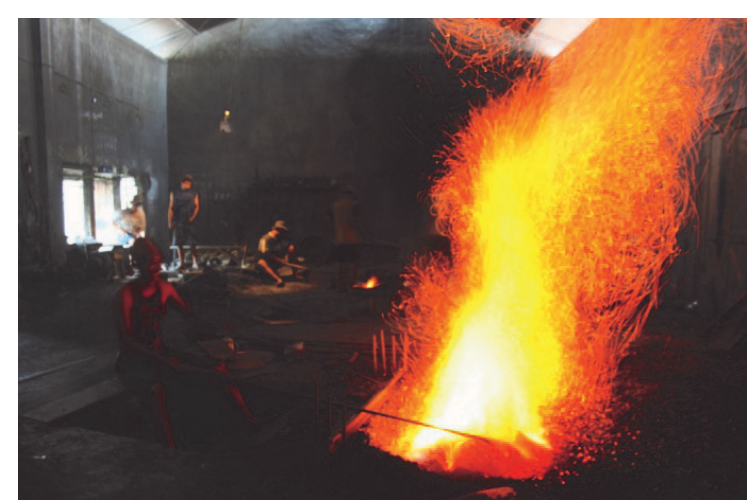

Gambar 5. Letupan api perapen Foto: I Gusti Ngurah Sudibya, 2014

Tembuku, Geria Nyere Tampaksiring, mengatakan bahwa api dalam diri walau tidak kasat mata ada dalam wujud api menyala, tetapi unsur panas pasti ada, karena darah yang beredar dalam tubuh manusia diakibatkan oleh kerja jantung sebagai sumber panas dalam tubuh. Jika jantung berhenti maka manusia disebut mati, maka dari itu manusia yang sudah mati, badannya pasti dingin (Wawancara, 20 Oktober 2014). Kebenaran api tidak saja kebenaran secara nyata (sekala) tetapi sekaligus juga memiliki kebenaran tidak nyata (niskala). Karena semua itu kembali kepada api secara kontekstual.

Masih banyak kebenaran dari api yang dapat dilihat dan dirasakan di sekitar kita. Semua ini adalah ungkapan kebenaran yang tidak dapat disangkal. Demikianlah, hendaknya kita sebagai manusia untuk selalu berbuat yang benar untuk kepentingan diri sendiri, lingkungan, bangsa, dan negara.

Tedapat lima aspek bentuk api alam, yakni:

a. Agni (api) pada umumnya, yaitu api yang nyata atau yang potensial, yang tersembunyi dalam minyak.

b. Vayu (Indra), kekuatan berupa petir yang bersembunyi di dalam mendung, api angkasa, api antara bumi dan langit.

c. Surya (matahari), api wilayah angkasa yang menerangi bumi.

d. Vaisvanara (yang meresapi segalanya), api kekuatan untuk mencerna, ditemukan di semua benda dan tubuh mahluk hidup. Api yang menyokong kehidupan. 
e. Api yang memusnahkan (Vadava Agni). Wujud api ini sangat menakutkan yang lahir dari dasar air dan masih tersembunyi dibawah lautan yang senantiasa siap untuk menghancurkan dunia (Ibid, 9).

Demikianlah, api hendaknya dijaga keberadaannya dan digunakan dengan benar agar manusia yang memanfaatkan api untuk kehidupan selalu mendapat rido dari Tuhan Yang Maha Kuasa. Termasuk menjaga lingkungan kita agar panas bumi dan matahari tetap stabil, sehingga bumi dapat berputar sebagaimana mestinya.

\section{Api dalam Keindahan}

Keindahan kata dasarnya adalah "indah". "Indah" bisa ditimbulkan oleh alam seperti stalagnit/stalagtit, bulu ekor burung merak, pelangi, lereng gunung, matahari terbit dan terbenam, air terjun, dan lain sebagainya yang memang tidak ada campur tangan manusia.

Ciptaan manusia juga dapat menghasilkan sesuatu yang indah, seperti lukisan, gerak tari, penataan kostum, permainan warna-warni cahaya lampu dan lain sebagainya yang memang bersumber dari olah rasa dan karsa manusia. Secara umum, indah menurut Djelantik dalam buku Pengantar Dasar Ilmu Estetika disebutkan bahwa, "indah dapat menimbulkan dalam jiwa kita rasa senang, rasa bahagia, rasa tenang, nyaman, dan bila kesannya lebih kuat, membuat kita terpaku, terharu, dan timbul keinginan untuk kembali menikmatinya" (Djelantik, 1990: 1).

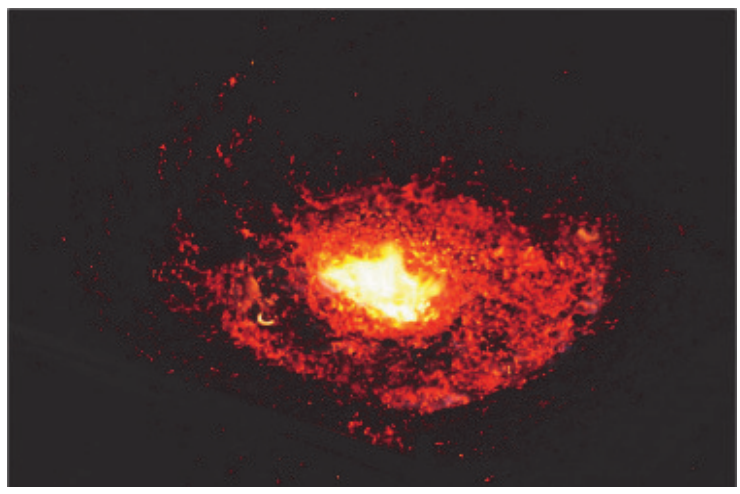

Gambar 6. Bara perapen seperti gugusan planet Foto: I Gusti Ngurah Sudibya, 2014
“Cahaya alam tidak banyak yang menjadikannya sebuah karya seni, padahal dengan karakternya ia mampu memberikan kesan indah, hanya dibutuhkan kemampuan dan waktu khusus untuk meresponnya" (Sudibya, 2012:69). Ketika lubang dinding dilewati cahaya matahari sore, kisaran pukul 16:00-17:00 WITA, tampak kepulan asap relatif tebal yang memberi kesan indah. Hal itu karena asap tersebut bergerak di antara ruang cahaya matahari dibantu hembusan angin yang selalu berubah. Berbeda pula ketika menghanyutkan beberapa api lilin di parit kecil. Ia bergerak mengikuti arus air tetapi tidak tentu arah, ada yang agak ke kiri, ada yang ke kanan, ada yang di tengah, ada yang berbenturan, tetapi semua bergerak perlahan dan tenang dalam gelap yang pekat memberi kesan indah juga.

Indah merupakan sebuah kata yang digunakan untuk sesuatu yang ditangkap oleh indera manusia sehingga menimbulkan rasa terpesona dalam dirinya. Seperti yang ditulis oleh Ida Bagus Mantra dalam majalah Cintamani, bahwa "estetika yang selama ini cenderung diartikan sempit, harus dimaknai sebagai keindahan yang dapat merangsang dan mendorong manusia untuk berkreasi dan bersikap dinamis untuk mencapai kepuasan batin dan mempertajam intuisinya" (Dibia, 2003: 95). Jadi, indah saja tidak cukup, bagaimana indah itu

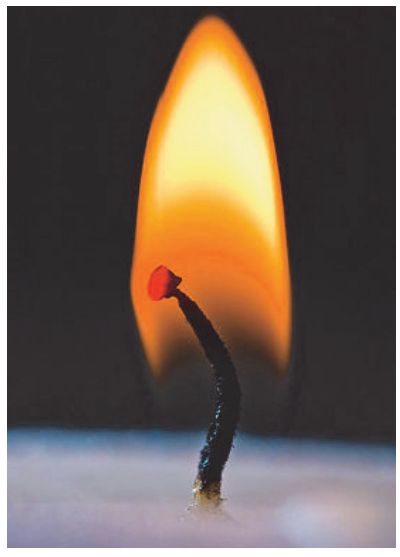

Gambar 7. Simulasi api hitam (transparan) pada pangkal benang

Foto: www.apakabardunia.com, 22/5/2017 


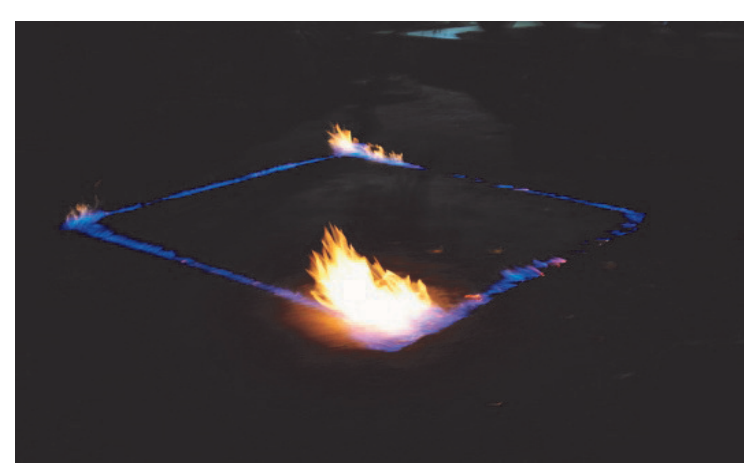

Gambar 8. Percobaan membakar dengan spiritus Foto: I Gusti Ngurah Sudibya, 2014

mampu memberi nilai lebih sehingga bermanfaat bagi semua pihak. Bagi seniman keindahan diartikan, "semua pengalaman hidup manusia yang tidak menyenangkan dapat diungkapkan dalam penampilan seni (indah), baik bersifat badani maupun rohani" (Lodra, 2012: 17).

Api secara fisik sudah memiliki keindahan tersendiri. Hal ini dapat dilihat dari gradasi cahaya dan warna yang ditimbulkan dari perbedaan kualitas panasnya. Dalam observasi di perapen dalam proses pembuatan gamelan, setelah gong diangkat dari tempat pembakarannya di atas bara api, bara yang disemprot dengan blower, nampak perbedaan gradasi cahaya dan warna dari titik tengah sampai lingkar luarnya. Seperti gugusan bintang yang memiliki inti, semakin menjauh dari inti semakin memudar cahaya bara apinya. Seperti tampak pada gambar 6 .

Sebagai ilustrasi, kualitas panas memberi efek pada warna api yang berbeda. Api memiliki warna merah pada suhu di bawah 1000 derajat. Sedangkan api biru kebanyakan digunakan untuk memasak dengan suhu rata-rata kurang dari 2000 derajat. Sementara api putih memiliki suhu di atas 2000 derajat seperti inti matahari, dan yang terakhir adalah api hitam yang nampak transparan. (www.apakabardunia.com, 22/5/2017). Simulasinya seperti terlihat pada gambar 7 .

Dalam percobaan yang dilakukan dengan membakar spiritus, tampak perbe-

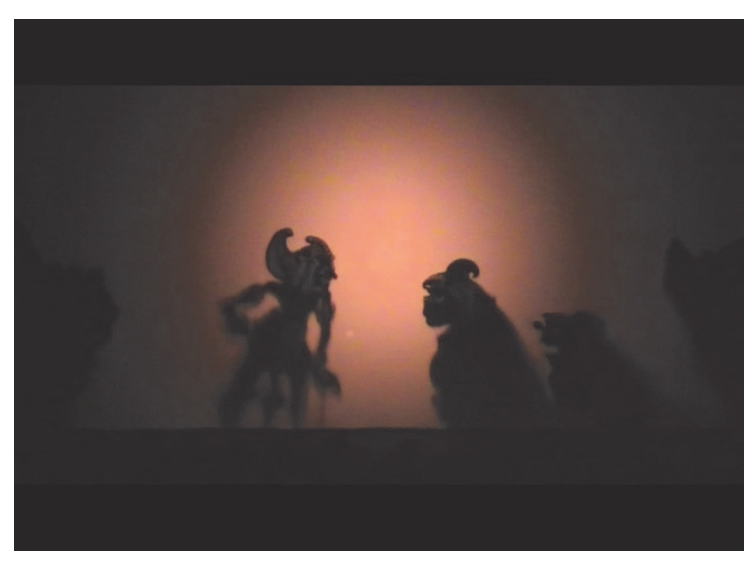

Gambar 9. Pementasan wayang berjudul Bima Ngambul

Foto: I Gusti Ngurah Sudibya, 2017.

daan warna api antara penggunaan bahan bakar (spiritus) yang sedikit dengan yang banyak. Jumlah yang berbeda ini menimbulkan perbedaan warna sekaligus keindahan tersendiri pada segi empat tersebut. Ia memiliki dinamika cahaya. Belum lagi hembusan angin yang membawa gerak dan arah api berubah-ubah.

Di sisi lain, api digunakan untuk memunculkan keindahan yang lain pula. Seperti dalam penampilan wayang purwa/wayang peteng yang menggunakan api atau lampu blencong sebagai penerangannya. Bayangan wayang di kelir selalu bergerak akibat dari api dalam lampu blencong yang bergerak dinamis. Tetapi, posisi wayang yang nempel dan tidak ada jarak dengan kelir membuat bayangan wayang diam (mati). Maka, posisi wayang juga menentukan gerak bayangannya. Gerak bayangan ini, selain menimbulkan kesan hidup, ia juga memberikan kesan indah dari tajam tipisnya bayangan wayang. Bayangan wajah tokoh lebih tajam daripada bayangan anatomi tubuh wayang bagian bawah belakang. Hal ini disebabkan adanya perbedaan jarak wayang dengan kelir. Wajah wayang menempel kuat pada kelir, sedangkan bagian punggung/belakang wayang memiliki jarak dengan kelir, sehingga bayangannya menjadi blur/tidak tajam. Bayangan yang tidak tajam inilah mengikuti gerak api dari lampu blencong. 


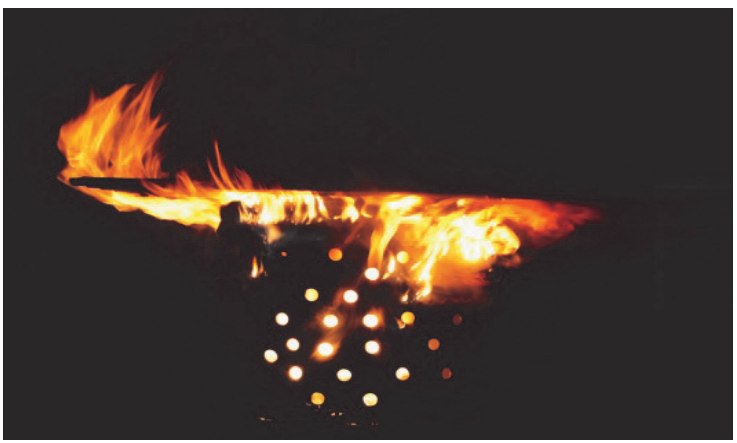

Gambar 10. Api drum

Foto: I Gusti Ngurah Sudibya, 2014

Eksperimen tersebut menunjukkan gerak api dengan mencari celah sendiri untuk keluar dari kondisi panas dalam drum yang tertutup. Ia mencari celah dan membuat ruang-ruang baru dengan bentuk yang berbeda sesuai dengan celah yang ada. Dengan bahan bakar kain, sumbu kompor dicampur minyak tanah, sehingga kobaran api yang ditimbulkan sangat jelas terlihat lebih galak. Taring apinya menjulai kemana-mana, terkesan garang, beringas, siap memakan apa saja yang berani masuk wilayahnya.

Sementara itu, ketika api obor disemprotkan dengan spiritus, api nampak lebih lembut dan geraknya tidak terlalu galak atau dinamis. Api mengikuti lintasan spiritus dan menghasilkan bentuk, warna yang menarik, dan indah.

Dari beberapa penjelasan dan eksperimen di atas, api menjadi indah ketika kita memperlakukannya dengan indah pula. Jika kita mampu melihat keindahannya, maka ia akan mampu memunculkan rasa indah (lango) meskipun pada kobaran api besar. Hal itu karena di sana ada gerak, lidah api yang menjulur secara dinamis ke arah yang tidak dapat diprediksi. Hukum ketidakberaturan menjadi teratur. Seperti pergerakan gugusan bintang dan planet di angkasa, bergerak masing-masing pada porosnya dan sangat tidak teratur, tetapi menjadi kosmis teratur dalam ketidakberaturan. Semua ini akibat peran penting panas bumi dan matahari (api). Cara kita

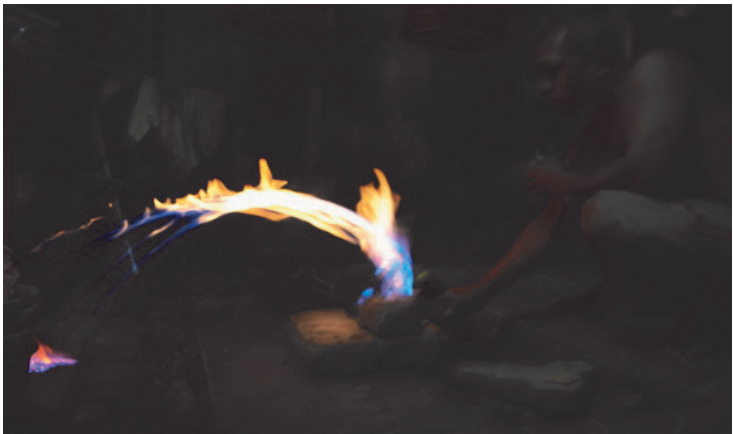

Gambar 11. Api obor disemprotkan spiritus Foto: I Gusti Ngurah Sudibya, 2014

melihat semua itu apakah berdiri sendiri dalam satu kesatuan utuh atau terpisah dalam kekuatan masing-masing, tergantung kebutuhan dan pemahaman kita terhadap nilai kesucian, kebenaran, maupun keindahan itu sendiri.

\section{SIMPULAN}

Api jika hanya dilihat sebagai teks, dia hanya memiliki pemahaman seperti apa adanya, apa yang terlihat oleh mata saja. Tetapi, jika kita mampu melihat api dalam konteks yang lebih luas, maka ia bermakna sangat dalam, tergantung pada pengetahuan yang dimiliki oleh pengamat. Nilainilai yang terkandung di dalamnya dapat dijadikan tauladan dalam menjalani hidup karena api terbentuk dari sebuah formulasi yang tepat antara panas dengan bahan mudah terbakar serta oksigen. Sebuah nilai kerjasama, sinergi dalam kapasitas masing-masing, dapat diaplikasikan dalam diri dan lingkungannya.

Keberadaan api sangat membantu kehidupan manusia baik dari sisi ekonomi, sosial, politik, budaya, maupun spiritual; dari yang miskin sampai yang kaya, dari desa sampai ke kota, dari pantai sampai ke gunung, semua menggunakan api untuk membantu kelangsungan hidup alam beserta isinya. Tetapi, api juga dapat menghancurkan dan meluluhlantakkan manusia dan lingkungan jika tidak mampu mengendalikannya. Api menjadi satu kesatuan dalam kehidupan masyarakat Bali. Api mengajar- 
kan kebenaran, api mengajarkan kesucian, sekaligus api memberikan keindahan. Api dapat dilihat secara terpisah, tetapi dapat pula dilihat sebagai satu objek yang memiliki nilai kesucian, kebenaran, dan keindahan.

Api ada di luar dan ada di dalam diri. Terkait hal itu, maka api yang ada dalam diri hendaknya dijaga untuk keharmonisan antara kita dengan Maha Pencipta, dengan sesama manusia, dan dengan lingkungan di mana kita berada. Dengan Maha Pencipta, hendaknya kita selalu bersyukur atas "api" yang telah diciptakan. Dengan sesama manusia, hendaknya mampu bersinergi, saling membantu, memanfaatkan "api" yang ada dalam dirinya untuk kemajuan bersama, serta dengan lingkungan, agar menjaga setiap "api" yang ada untuk ekosistem yang berkelanjutan. Api sebagai simbol ilmu pengetahuan yang ada dalam diri hendaknya diaplikasikan untuk kehidupan yang lebih baik sesuai dengan tempat, waktu, dan keadaan. Di mana, kapan, dan dalam kondisi apa kita menggunakan api kecil, sedang, maupun besar, semuanya penting. Api sebagai kawan maupun lawan sesungguhnya ada dalam diri masing-masing.

\section{Ucapan Terimakasih}

Ucapan terimakasih disampaikan kepada Prof. Dr. Pande Made Sukerta, S.Kar., M.Si., Prof. Sardono W. Kusumo, dan Dr. Eko Supriyanto, S.Sn., M.F.A. sebagai Promotor dan ko Promotor 1, 2, yang dengan penuh kesabaran dan keikhlasan telah meluangkan waktu, tenaga, dan pikirannya untuk membimbing dalam proses belajar mengajar. Kepada yang dimulyakan, para Pedanda yang telah memberikan informasi sekaligus motivasi untuk menginformasikan nilai-nilai yang terkandung dalam api, kepada masyarakat luas melalui karya seni.

\section{Daftar Pustaka}

Chaya, I N. (2014). Intensitas Budaya dalam
Dunia Kepenarian. Panggung, 24 (3), 295 -307.

Djelantik, A A M. (1990). Pengantar Dasar Ilmu Estetika. Denpasar: STSI Denpasar.

Maharani, I. A. D. (2016). Representasi Nilai Kosmologi pada Wujud Lokal Bangunan Hunian Bali Age, Panggung, 26 (4), 394 - 406.

Kadjeng, I N. (1997). Sarasamuscaya. Surabaya: Paramita.

Kaler, I G. K. (1993). Ngaben, Mengapa Mayat Dibakar? Pustaka Bali Post, Denpasar.

Kasyap, R. L. (2008). Kekuatan Dewa Agni dan Dewa Indra (Manifestasi Kekuatan Keinginan dan Mental dalam diri kita). Surabaya: Paramita.

Lodra, I N. (2012). Estetika Hindu di Era Globalisasi. Jurnal Seni Rupa, 11 (1), 12-25.

Mulasno, T. (2007). Pertunjukan Wayang Kulit Parwa pada Upacara Syawalan di Dukuh Dadimulyo, Desa Krecek, Kecamatan Delanggu, Kabupaten Klaten. Jurnal Dewa Ruci, Pengkajian dan Penciptaan Seni, 4 (2), 146-174.

Redaksi Pustaka Manik Geni. (1994). Doa Sehari-Hari Menurut Hindu. Jakarta: PT. Pustaka Manikgeni.

Sanjaya, G. O. (2001). Agni Purana. Surabaya: Paramita.

Sudibya, I G. N. (2012). Arsitektural Cahaya. Jurnal Agem, 11 (1), 67 - 98.

Suryabrata, S. (1997). Metodologi Penelitian. Jakarta: PT. Raja Grafindo Persada.

Tabloid Bali Niskala. (2017). Ngepus Caling Api, 38, 20.

Titib, I M. (2003). Teologi dan Simbol-Simbol dalam Agama Hindu. Surabaya: Paramita.

Triguna, I. B. G. Y. (2003). "Estetika Hindu dan Pembangunan Bali" dalam Nilainilai Estetika Hindu dalam Kesenian Bali. (ed) I Wayan Dibia. Denpasar: Widya Dharma, Universitas Hindu Indonesia. (2000). Teori tentang Simbol. Denpasar: Widya Dharma, Universitas Hindu Indonesia. 
Widaryanto, F. X. (2015). Ekokritikisme Sardono W. Kusumo: Gagasan, Proses Kreatif, dan Teks-Teks Ciptaanya. Surakarta: Program Pascasajana Institut Seni Indonesia Surakarta.

Wikarman, I N. S. (2006). Caru Palemahan dan Sasih. Surabaya: Paramita.

Yendra, I W. (2010). Kanda Pat Rare. Surabaya: Paramita.

\section{Webtografi}

Ritus Kematian Zoroastrianisme, 25/3/2018, retrieved from https://id.wikipedia. org/wiki/Zoroastrianisme

Obor Api Porprov Bali XIII Diambil dari Pura Hyang Api, 25/3/2018, retrieved from http://koranjuri.com/obor-apiporprov-bali-xiii-diambil-dari-purahyang-api/. 